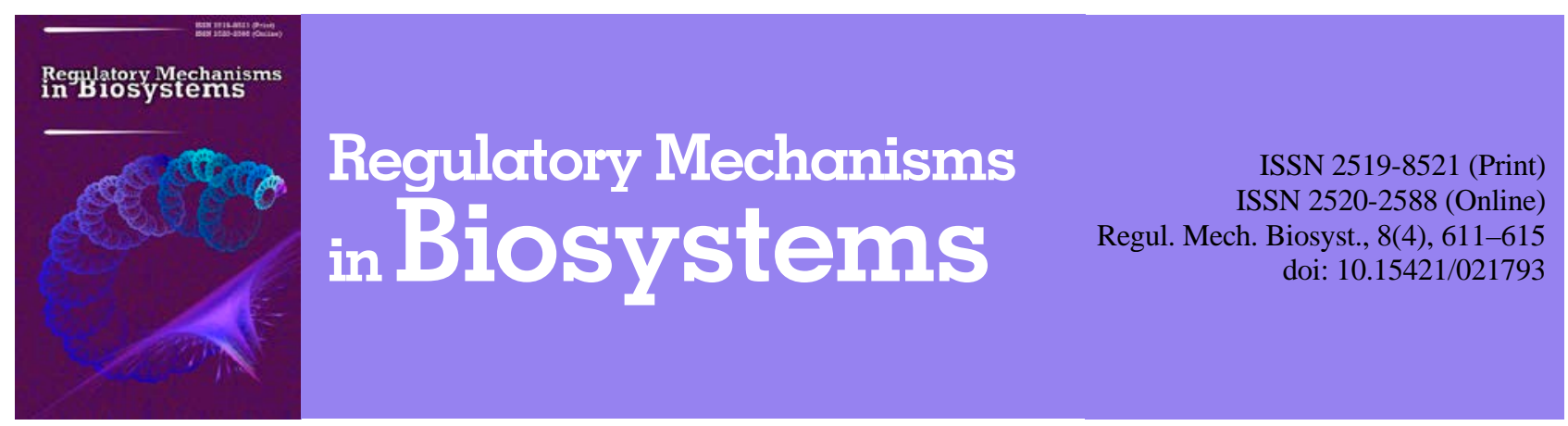

\title{
Features of the microbiota of the urogenital tract of women with pathological conditions
}

\author{
Y. M. Bezkrovna, L. P. Golodok, A. I. Vinnikov \\ Center of Laboratory Diagnostics, LLC "Medlayf", Kremenchug, Ukraine \\ Oles Honchar Dnipro National University, Dnepr, Ukraine
}

Article info

Received 28.09.2017

Received in revised form 04.11.2017

Accepted 08.11.2017

Oles Honchar Dnipro National University, Gagarin Ave., 72

Dnipro, 49010, Ukraine.

Tel.: +38-097-300-54-79.

E-mail: bezk-yuliya@yandex.ru
Bezkrovna, Y. M., Golodok, L. P., \& Vinnikov, A. I. (2017). Features of the microbiota of the urogenital tract of women with pathological conditions. Regulatory Mechanisms in Biosystems, 8(4), 611-615. doi:10.15421/021793

Nonspecific infection of the female reproductive system continues to occupy the first place among pathologies of the reproductive tract of the female. These diseases affect the organs and tissues related to the reproductive system. Using the method of polymerase chain reaction in real time, we investigated characteristics of the normal and conditionally pathogenic aerobic / facultative anaerobic, anaerobic biota in the urethra, cervical canal and vagina of women aged 16 to 58 years, studies were carried out on the basis of the Center of Laboratory Diagnostics, LLC "MEDLAYF". For all women up to the age of 40, biota is mainly represented by lactobacilli (Lactobacillus spp.), and in pathological complications of the urogenital tract of women the microbial composition of the biocoenosis is characterized by a decrease in the number of lactobacilli and their replacement by pathogenic anaerobic microorganisms. In disorders of the microflora of the urogenital tract we also detected the human papillomavirus of both high and low carcinogenic risk and Ureoplasma (urealiticum + parvum), Chlamydia trachomatis, Trichomonas vaginalis, Mycoplasma hominis and yeast of the genus Candida spp. The most frequently distributed of the most common causative agents of pathological conditions of the reproductive system of women is the human papillomavirus of high carcinogenic risk, Ureoplasma (urealiticum + parvum) and Candida spp. This is due to anatomical and physiological characteristics of the genital organs, hormonal and immune system.

Keywords: PCR in real time; reproductive age; urogenital tract; dysbiosis; microorganisms

\section{Особливості мікробіоти урогенітального тракту жінок за патологічних станів}

\author{
Ю. М. Безкровна, Л. П. Голодок, А. І. Вінніков
}

Центр лабораторної діагностики ТОВ «Медлайф», Кременчук, Україна

Дніпровський начіональний університет імені Олеся Гончара, Дніпро, Україна

Неспецифічні інфекції жіночої статевої системи продовжують посідати одне з перших місць серед патологій репродуктивного тракту жінки. Ці хвороби негативно впливають на органи та тканини, які належать до репродуктивної системи. За допомогою методу полімеразної ланцюгової реакції у режимі реального часу досліджено характеристики нормальної та умовно-патогенної аеробної або факультативно-анаеробної, анаеробної біоти в уретрі, цервікальному каналі та піхві жінок віком 16-58 років. В усіх жінок до 40 років біота представлена переважно лактобацилами (Lactobacillus spp.), а за патологічних ускладнень урогенітального тракту жінок мікробний склад біоценозу характеризується зниженням кількості лактобацил і заміщенням їх умовно-патогенними анаеробними мікроорганізмами. За порушення мікрофлори урогенітального тракту також виявлено вірус папіломи людини високого та низького канцерогенного ризику та Ureoplasma (urealiticum + parvum), Chlamydia trachomatis, Trichomonas vaginalis, Mycoplasma hominis та дріжджі роду Саndida. За частотою виділення найпоширеніші збудники патологічних станів репродуктивної системи жінок - вірус папіломи людини високого канцерогенного ризику, Ureoplasma (urealiticum + parvum) i Candida spp. Це пов’язано з анатомо-фізіологічними особливостями статевих органів, гормональним фоном і станом імунної системи.

Ключові слова: ПЛР у режимі реального часу; репродуктивний вік; урогенітальний тракт; дисбіоз; мікроорганізми Вступ

Останніми десятиліттями відмічають ріст дисбіотичних захворювань урогенітального тракту жінок. Зміни екологічного стану довкілля, нераціональне харчування, перенесені гострі кишкові інфекції, хронічні захворювання та дисфункція шлун- ково-кишкового тракту, широке застосування антибіотиків, зниження імунологічної реактивності організму можуть бути причинами порушень рівноваги представників резидентної мікрофлори та виникнення дисбактеріозу піхви (Machado and Cerca, 2015). Один із важливих факторів резистентності жіночих статевих органів до урогенітальних інфекцій, які переда- 
ються статевим шляхом, - нормальна мікрофлора піхви. У здорових жінок репродуктивного віку вона характеризується більшим різноманіттям видів бактерій, життєдіяльність яких багато в чому залежить від їх здатності до адгезії на клітини піхвового епітелію та можливості конкуренції між собою за місця перебування та продуктами харчування. Мікрофлора піхви здорових жінок репродуктивного віку включає широкий спектр мікроаерофілів, факультативних і облігатних анаеробів.

За фізіологічної норми жіночий організм контактує з тисячами видів мікробів, перебуваючи з ними у симбіотичних відносинах. За впливу ендогенних і екзогенних чинників відбувається постійна зміна мікробіоти вагінального біотопу, що викликає порушення складу нормальної мікрофлори. Зменшення кількості лактобацил та збільшення анаеробних представників мікрофлори може спричинити дисбіоз (Algeburi et al., 2015). Видовий склад лактобактерій піхвового біотопу в кожної жінки унікальний, нерідко представлений декількома видами. Нині класифіковано понад 150 лактобактерій, із них, за даними різних авторів, у піхві здорових жінок може бути від 6 до 15 видів. Найчастіше зустрічаються Lactobacillus acydophilus, L. paracasei, L. crispatum, L. brevis.

Вагінальна флора може змінюватися в різні фази менструального циклу. Найменша кількість мікроорганізмів визначається у період менструації. Деякі автори вважають, що число аеробів упродовж менструального циклу досить постійне, а кількість анаеробів може змінюватися (Reid et al., 2003). Тому можливі варіації нормального мікробоценозу піхви.

Мікрофлора урогенітального тракту представлена в основному мікробіотою (бактеріальні мікроорганізми), мікобіотою (гриби), а також вірусами та найпростішими, сукупність яких забезпечує колонізаційну резистентність. Лактобацили домінують у мікрофлорі піхви, але за останні роки з'являється все більше даних про те, що збільшилося різноманіття мікробіоти піхви у поєднанні зі зниженою чисельністю Lactobacillus spp. У свою чергу, це викликає підвищення рівня патогенних мікроорганізмів і зараження вірусними агентами, які спричиняють передрак і рак шийки матки (Mitra et al., 2017).

Нині це одна 3 найважливіших медико-соціальних проблем інфекційна патологія репродуктивної системи жінки. Провідне місце у структурі цієї патології посідають запальні процеси, викликані умовно-патогенними мікроорганізмами. За даними Larsen et al. (2001) i Klebanoff et al. (2004), частота бактеріальних інфекцій урогенітального тракту сягає 80\% серед патологічних станів жіночої статевої сфери. Розвиток дисбалансу біоти урогенітального тракту може супроводжуватися метаболічними та імунними порушеннями, та в низці випадків клінічними проявами, ступінь вираженості яких варіює від безсимптомного носійства до виражених клінічних проявів (Ferris et al., 2004). Порушення нормальної мікрофлори репродуктивного тракту можуть спричиняти переривання вагітності, передчасні пологи, внутрішньоутробне інфікування плода та післяпологові ускладнення в матері (Nikulina et al., 2012). Дослідження Aila et al. (2010) показали, що майже у 50\% випадків на первинному прийомі діагностується ускладнений перебіг урогенітальних інфекцій у жінок.

Збільшення кількості хворих на неспецифічні інфекції, труднощі терапії, пов’язані з антибіотикорезистентністю збудників, складністю та неясністю багатьох питань механізму розвитку захворювання, відсутністю чітких критеріїв діагностики та впливу інфекції на репродуктивну систему, роблять цю проблему надзвичайно актуальною. Метод полімеразної ланцюгової реакції у реальному часі дозволяє виявити збудників у низькій концентрації, а також діагностувати дисбіотичні порушення на ранніх етапах, коли можливо запобігти подальшому розвитку складних патологічних станів.

Мета цього дослідження - встановити частоту виявлення умовно-патогенних мікроорганізмів та вірусів урогенітального тракту жінок в умовах патологічних ускладнень.

\section{Матеріал і методи досліджень}

На першому етапі для аналізу співвідношення аеробної та анаеробної мікрофлори обстежили 175 жінок віком 16-58 років, при цьому застосовано метод полімеразної ланцюгової реакції в реальному часі. Залежно від ступеня вираженості клінічних проявів пацієнток поділили на дві групи: «норма» (110 жінок, які не мали суб'єктивної та об'єктивної клінічної симптоматики) та «патологія» (65 пацієнток, які пред’являли скарги за відсутності об'єктивної клінічної та наявної суб'єктивної симптоматики). У частини здорових жінок фертильного віку (старше 40 років) відбувається зниження колонізації урогенітального тракту лактобацилами порівняно 3 молодшими фертильними жінками. У зв'язку із цим жінок із груп «норма» та «патологія» залежно від віку поділили на три групи: I - 16-25 років, II - 26-39 і III вікова група $-40-58$ років.

У жінок відбирали клінічні зразки шляхом скребка з поверхні епітелію із задньобокового склепіння піхви та цервікального каналу стерильним одноразовим інструментом типу «Cutobrush». Зразок поміщали у пробірку з транспортним середовищем.

На наступному етапі обстежено 125 жінок віком 16-58 років. Для виявлення вірусу папіломи людини високого та низького канцерогенного ризику, а також інших вірусних агентів, усіх пацієнток поділено на три вікові групи, зазначені вище. Цей поділ зроблений з метою детального вивчення розповсюдження вірусу папіломи людини та інших вірусних агентів в урогенітальному тракті жінок різного репродуктивного віку. Всім досліджуваним проведене комплексне обстеження та гінекологічний огляд.

Для цього етапу застосовано тест-системи «Фемофлор» i «Квант-21» для проведення полімеразної ланцюгової реакції в режимі реального часу. Клінічний матеріал із піхви відбирали за допомогою одноразового стерильного зонда із заднього або бічних зводів шляхом скребка з поверхні епітелію, матеріал із цервікального каналу отримали за допомогою уретрального зонда, який потім поміщали в пробірки з транспортним середовищем.

\section{Результати}

Методом полімеразної ланцюгової реакції в режимі реального часу дослідили склад мікрофлори урогенітального тракту 175 жінок різних вікових категорій, що звернулись до Центру лабораторної діагностики ТОВ «Медлайф» (м. Кременчук, (табл.).

\section{Таблиця}

Частота виділення аеробних і анаеробних бактерій урогенітального тракту жінок, які не мали суб’єктивної та об'єктивної клінічної симптоматики

\begin{tabular}{clccc}
\hline \multirow{2}{*}{ Вид мікроорганізму } & \multicolumn{3}{c}{ Частота виділення клінічних } \\
& & штамів мікроорганізмів, \% \\
\cline { 3 - 5 } & & $16-25$ & $26-39$ & $40-58$ \\
& років & років & років \\
& & $\mathrm{n}=50$ & $\mathrm{n}=40$ & $\mathrm{n}=20$ \\
\hline \multirow{5}{*}{ Аеробна } & Lactobacillus spp. & 90 & 70 & 45 \\
мікрофлора & Esherichia coli & 10 & 10 & 10 \\
& Staphylococcus aureus & 5 & 8 & 5 \\
& Candida albicans & 3 & 10 & 5 \\
\hline \multirow{5}{*}{ Анаеробна } & Atopobium vaginae & 0 & 20 & 20 \\
& Megasphaera spp. & 0 & 8 & 10 \\
& Dialister spp. & 0 & 8 & 10 \\
& Gardnerella vaginalis & 3 & 10 & 15 \\
& Porhyromonas spp. & 0 & 0 & 5 \\
& Eubacterium spp. & 0 & 0 & 10 \\
\hline
\end{tabular}

У жінок віком 16-25 років кількість умовно-патогенних мікроорганізмів відповідала нормоценозу, а у пацієнток понад 40 років зі зниженою кількістю лактобацил виявлено збільшення кількості анаеробних умовно-патогенних мікроорганізмів, у жінок віком 26-39 років відмічали незначне збільшення кількості анаеробних умовно-патогенних мікроорганізмів. Таким 
чином, у жінок понад 40 років за відсутності атрофічних змін в урогенітальному тракті відбувається заміщення лактобацил на широкий спектр анаеробних бактерій (рис. 1) У жінок молодше 25 років частота виявлення лактобацил становить $90 \%$, співвідношення аеробних і анаеробних мікроорганізмів відповідало нормоценозу, а частота виділення анаеробних бактерій у всіх обстежених понад 40 років, на відміну від аеробних (факультативно-анаеробних), перевищувала рівень лактобацил (45\%).

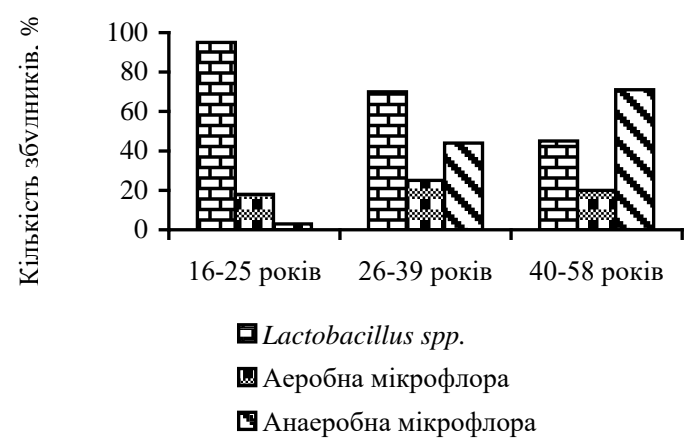

Рис. 1. Співвідношення аеробних і анаеробних мікроорганізмів урогенітального тракту жінок без суб'єктивної та об’єктивної клінічної симптоматики $(\mathrm{n}=110)$

Вивчення частотного розподілу мікроорганізмів показало, що у більшості жінок без суб'єктивної та об'єктивної клінічної симптоматики умовно-патогенні збудники не виявлені, реєструються лише поодинокі випадки у вигляді бактеріальної моноінфекції. Проводячи дослідження серед жінок, що пред’являли скарги за відсутності об'єктивної та наявності суб'єктивної клінічної симптоматики (група «патологія»). виділили такі умовно-патогенні штами мікроорганізмів: Ureoplasma (urealiticum + parvum), Chlamydia trachomatis, Trichomonas vaginalis, Mycoplasma hominis, Candida spp., Neisseria gonorrhoeae (рис. 2).

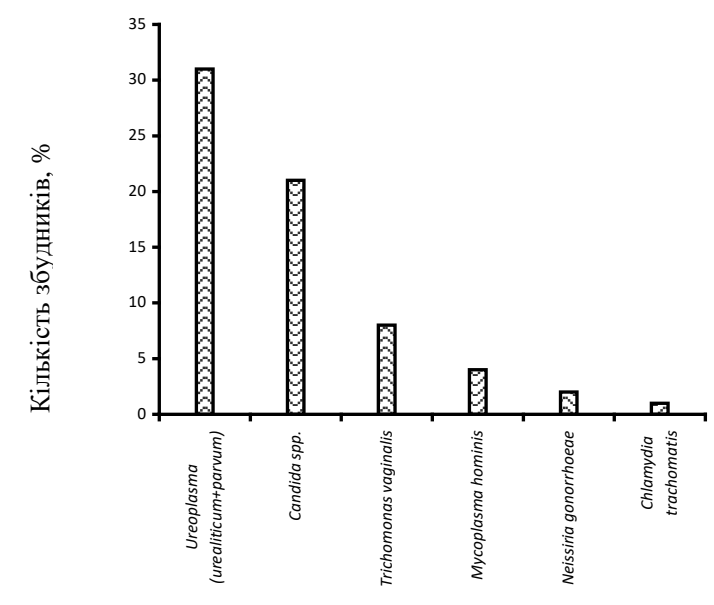

Рис. 2. Частота виявлення патогенних

і умовно-патогенних мікроорганізмів $(\mathrm{n}=65)$

В усіх вікових групах жінок, які пред’являли скарги за наявності суб'єктивної клінічної симптоматики, виділені мікроорганізми у досліджуваному клінічному матеріалі містилися майже в однаковому відсотковому співвідношенні. У високих титрах виявлено Ureoplasma (urealiticum + parvum) $\left(>10^{4}, 31 \%\right)$ та Candida spp. (21\%). У 8\% жінок виявлено Trichomonas vaginalis, y 4\% - Mycoplasma hominis, y 1\% - Chlamydia trachomatis та у $2 \%$ - Neisseria gonorrhoeae. Слід зазначити, що в усіх жінок групи «патологія» відмічено зниження рівня Lactobacillus spp. Можна зробити припущення, що найвірогідніша причина появи різних патологічних ускладнень за відсутності об' єктивних клінічних ознак запалення в урогенітальному тракті, за даними наших спостережень, - великий відсоток частоти виявлення Ureoplasma (urealiticum + parvum) та Candida spp., а також зниження рівня нормальної мікрофлори урогенітального тракту. У рідкісних випадках має значення також і великий спектр інших збудників запальних процесів урогенітального тракту жінок, у тому числі патогенних.

Таким чином, за відсутності об’'єктивних клінічних симптомів запалення наявне як у жінок віком 26-39 років, так і у жінок віком понад 40 років та виявляється частіше, ніж у пацієнток, які не мають суб'єктивної та об’ єктивної клінічної симптоматики. Така поширеність збудників може бути пов'язана з тим, що у жінок репродуктивного віку (26-39 років) відбуваються зміни мікрофлори урогенітального тракту, пов'язані 3 пологами, а також із вагітністю, соціальними умовами, частотою зміни статевих партнерів (Newton, 2001). Особливе значення у патології репродуктивної системи має вірус папіломи людини високого та низького канцерогенного ризиків, тому проведено аналіз поширення різних типів вірусу папіломи людини у різних вікових групах жінок.

У віковій групі 16-25 років виявлено 12 типів вірусу папіломи людини високого канцерогенного ризику. Найчастіше виявлявся 16-й тип (18,4\%), інші типи виявлялися у незначних відсотках, також у першій віковій групі виділено вірус папіломи людини низького канщерогенного ризику 11 (2,6\%) (рис. 3).



Рис. 3. Кількість різних типів вірусу папіломи людини (\%) у першій віковій групі (від 16 до 25 років)

У жінок другої вікової групи (26-39 років, рис. 4) вірус папіломи людини високого канцерогенного ризику виявлявся у вищих відсотках відносно першої вікової групи. 16-й тип складав (32,3\%), а 31-й (22,6\%) типи 35-й і 68-й не виявлені.

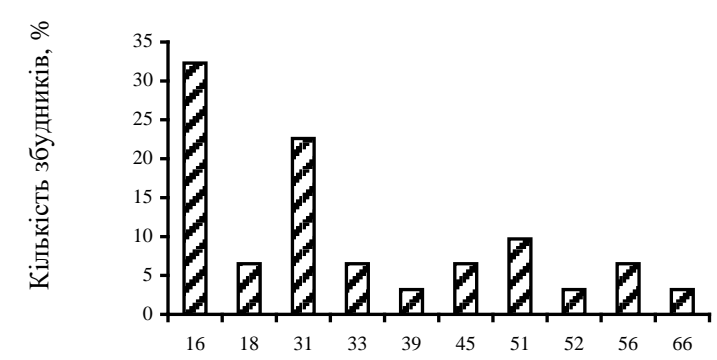

Рис. 4. Кількість різних типів вірусу папіломи людини (\%) у другій віковій групі (26-39 років)

У жінок третьої вікової групи (40-58 років) найчастіше виділяли 56-й тип (42,9\%), а також виділено $31,39,45,68$-й $(14,2 \%)$ типи. Інших типів вірусу папіломи людини $(16,18,33,35,51,52-и ̆$ високого та 11-й тип низького канцерогенного ризику) не виявлено. Це може бути пов'язано з поступовою елімінацією збудника 3 організму, що не викликало патологічних змін репродуктивного тракту жінок (рис. 5). 


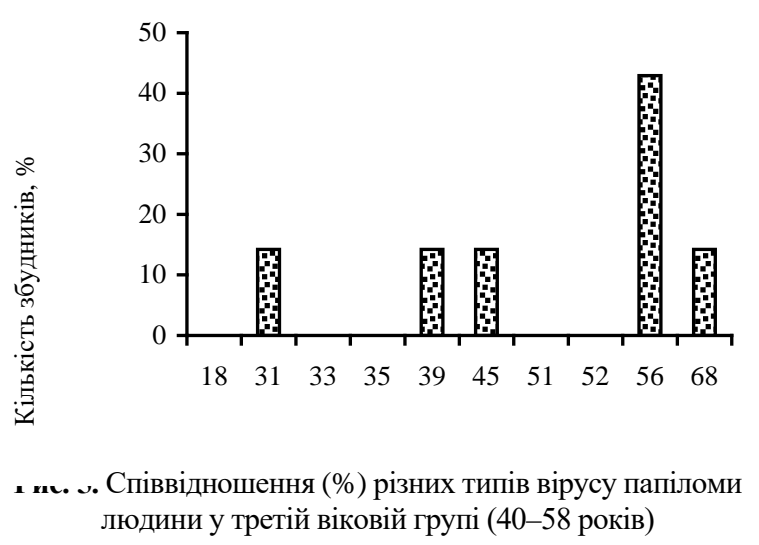

\section{Обговорення}

Порушення стану урогенітальної мікрофлори викликають багато факторів, які можна поділити на ендогенні та екзогенні. До ендогенних факторів відносять запальні захворювання яєчників, щитоподібної залози, захворювання шийки матки, перенесені раніше або супутні запальні захворювання сечостатевої системи, зниження імунологічної реакції організму, що викликають розвиток вірусних інфекцій. Екзогенні фактори - екологічні, санітарно-гігієнічні, клімато-географічні. Патологічні порушення складу урогенітального мікробоценозу відбуваються також за стресових впливів на макроорганізм: тривале застосування антибактеріальних препаратів, лікування гормонами цитостатиками, променева терапія, нервові потрясіння, використання внутрішньоматкових і оральних контрацептивів (Gupta et al., 2004).

Отже, за патологічного стану урогенітального тракту відбувається збільшення різноманіття піхвової мікробіоти у поєднанні зі зниженою чисельністю Lactobacillus spp., що, у свою чергу, спричиняє підвищення рівня умовно-патогенної мікробіоти та агентів вірусної природи. За даними Boldyrev et al. (2010), у жінок віком до 40 років кількість лактобацил склала $69 \%$, у жінок вікової групи 40-50 років відмічене зниження кількості лактобацил до $39 \%$. У жінок цієї вікової групи спостерігали перевищення кількості анаеробних бактерій відносно лактобацил удвічі. Potapov (2014) наводить фактори, за дії яких у піхві зменшується кількість лактобактерій i порушується мікробоценоз із ризиком розвитку бактеріального вагінозу, неспецифічного вагініту або вульвовагінального кандидозу.

Серед збудників інфекційно-запальних захворювань урогенітального тракту велику увагу фахівців привертають Ureaplasma urealyticum, Mycoplasma hominis і M. genitalium. Нині M. genitalium розглядається як абсолютний патоген, питання про значення $U$. urealyticum i M. hominis як збудників, які ініціюють розвиток патологічних процесів в урогенітальному тракті, залишається предметом дискусій. Дані про поширеність мікоуреаплазменної інфекції різні. Показники інфікованості населення репродуктивного віку коливаються, за даними низки авторів, у межах 4-50\%.

Наші дані збігаються із дослідженнями Konoplyanko et al. (2015), які показують, що у понад 50\% хворих виявляють хламідії: у $49,3 \%$ випадків - разом із гонококами, у 38,0\% - із мікоплазмами, у 32,0\% - із трихомонадами, у 25,2\% - із вірусом герпесу. Трихомоніаз також найчастіше перебігає у поєднанні 3 мікоплазменною (47,3\% випадків), гонококовою (29,1\%), гарднерельозною (31,4\%) та уреаплазмозною інфекцією (20,9\% випадків).

За даними Goncharova et al. (2015), у разі патологічних ускладнень репродуктивного тракту жінок відмічається висока частота реєстрації вірусу папіломи людини високого канцерогенного ризику (51,4\%), Ureaplasma urealyticum (28,2\%), Chlamydia trachomatis (7,0\%), Trichomonas vaginalis (3,5\%), дріжджі роду Candida spp. (2,8\%), Mycoplasma hominis (1,4\%) та вірусу папіломи людини низького канцерогенного ризику (1,4\%). Leli et al. (2017) показали частоту реєстрації $U$. urealyticum $(31,5 \%)$ та M. hominis (2,5\%) i також відзначили, що частота виявлення $M$. hominis у жінок, які пред’являли скарги, значно вища, ніж у тих, які не мали скарг.

Нині рак шийки матки - другий найпоширеніший вид раку у жінок. За даними de Sanjose et al. (2017), близько 5\% усіх випадків раку у світі спричинено в основному вірусом папіломи людини високого канцерогенного ризику $(16,18,31,33,35,39,45,51,52$, 56,58, і 59-й тип). Саме ці типи спричиняють інвазивний рак шийки матки та цервікальну інтраепітеліальну неоплазію. Folyak et al. (2010) дослідили співвідношення виявлення раку шийки матки та типування вірусу папіломи людини: виявили 17 типів вірусу папіломи людини високого $(16,18,31,33,35,39,45,51,52$, $53,56,58,59,66,68,73$ і 82-й) та 7 низького канцерогенного ризику $(6,11,42,43,61,81$ та 83-й). Нашим дослідженням також виявлено більшість цих типів вірусу, що корелює з їх дослідженнями. Tian et al. (2017) показали, що найпоширеніші генотипи вірусу папіломи людини - 6-й (11,8\%), 16-й (11,2\%), 11-й (10,8\%), 51-й $(7,0 \%)$ і 18-й (5,4\%). Під час дослідження жінок виявляється принаймні один із 37 генотипів вірусу папіломи людини 3 високим канцерогенним ризиком, а також вірус папіломи людини 3 низьким ризиком. Дані Hafsa (2017) також показують, що найчастіше виявляють у жінок вірус папіломи людини 18-го (6,3\%) та 16-го типів (4,2\%). Jacome-Galarza et al. (2017) з'ясували, що найвищий рівень папіломовірусної інфекції виявлений у вікових групах жінок, молодших 25 та віком 25-34 роки. Під час проведення нашого дослідження найчастіше вірус папіломи людини виявлений у вікових групах 16-25 та 26-39 років, тому наші дані збігаються з результатами їх досліджень.

Таким чином, можна відмітити тенденцію до зростання поширеності інфекцій різної етіології репродуктивного тракту жінок і показати значимість даних досліджень для призначення схем етіотропного лікування та проведення профілактики зараження інфекціями, які передаються статевим шляхом.

\section{Висновки}

Проведено аналіз складу мікрофлори урогенітального тракту 175 жінок різних вікових категорій за допомогою методу полімеразно-ланцюгової реакції в режимі реального часу, який показав, що у жінок, молодших за 25 років, частота виявлення лактобацил становить 95\%, співвідношення аеробних і анаеробних мікроорганізмів відповідає нормоцинозу, частота виділення анаеробних бактерій у всіх обстежених віком понад 40 років перевищувала рівень лактобацил (45\%). У жінок із відсутністю об’єктивної та наявністю суб'єктивної клінічної симптоматики в усіх вікових групах умовно-патогенні мікроорганізми містилися майже в однаковому відсотковому співвідношенні. У високих титрах у жінок репродуктивного віку виявлено Ureoplasma (urealiticum + parvum) $\left(>10^{4}\right.$, $31 \%$ ) та Candida spp. (21\%). У $8 \%$ жінок виявлено Trichomonas vaginalis, у 4\% - Mycoplasma hominis, в 1\% - Chlamydia trachomatis та у $2 \%$ - Neisseria gonorrhoeae.

Співвідношення агентів вірусної природи у жінок різних вікових категорій різниться. Серед усіх збудників патологічних станів репродуктивної системи жінок віком 16-25 років виділені віруси папіломи людини високого канцерогенного ризику типів 16 (18,4\%), 31 (13,2\%), 52 (10,5\%), 18, 46, 66, 68 (по 7,9\%), 35, 39, 51 (по 5,3\%), 33 і 56 (по 2,0\%), а також виділено вірус папіломи людини низького канцерогенного ризику 11 (2,6\%). Найчастіше виділяли віруси папіломи людини високого канцерогенного ризику у жінок репродуктивного віку $16(32,3 \%)$ i 31 (22,6\%). Типи 35-й i 68-й не виявлені. 3 віком частота виявлення вірусу папіломи людини високого канцерогенного ризику різко знижується: найчастіше виділено 56-й тип (42,9\%), інші типи вірусу папіломи людини $(16,18,33,35,51,52-и ̆$ високого і 11-й тип низького канцерогенного ризику) не виявлено.

\section{References}

Aila, N. A., Tency, L., Claeys, G., Verstraelen, H., \& Saerens, B. (2010). Comparison of different sampling techniques and of different culture methods for 
detection of group B Streptococcus carriage in pregnant women. World Journal of Preventive Medicine, 3(1), 167-285.

Algeburi, A., Volsci, A., \& Chicindas, M. L. (2015). Natural antimicrobials subtilosin and lauramide arginine ehyl esyer synergise with conventional antibiotics clindamycin Volsci, and metranidazole against biofilms of Gardnerella vaginalis but not against biofilms vaginal lactobacilli. Federation of European Microbiological Societies Pathogens and Disiase, 73(5), ftv018.

Balashov, S. V., Mordechai, E., Adelson, M. E., \& Gygax, S. E. (2014). Identification, quantification and subtyping of Gardnerella vaginalis in noncultured clinical vaginal samples by quantitative PCR. Journal of Medical Microbiology, 63(2), 162-175.

Bansal, A., Singh, M. P., \& Rai, B. (2016). Human papillomavirus-associated cancers: A growing global problem. International Journal of Applied and Basic Medical Research, 6(2), 84-89.

Baron, C., Henry, M., Tamalet, C., Villeret, J., Richet, H., \& Carcopino, X. (2015). Relationship between HPV 16, 18, 31, 33, 45 DNA detection and quantitation and E6/E7 mRNA detection among a series of cervical specimens with various degrees of histological lesions. Journal of Medical Virology, 87(8), 1389-1396.

Bendas, V. V. (2011). Features of collection of material for laboratory diagnosis of candidiasis. Clinical and Experimental Pathology, 5(4), 125-129.

Chan, P. K. (2012). Human papillomavirus type 58: The unique role in cervical cancers in East Asia. Journal Cell and Bioscience, 2(1), 17.

Choe, H. S., Lee, D. S., Lee, S .J., Hong, S. H., Park, D. C., Lee, M. K., Kim, T. H., \& Cho, Y. H. (2013). Performance of Anyplex II multiplex real-time PCR for the diagnosis of seven sexually transmitted infections: Comparison with currently available methods. International Journal of Infectious Diseases, 7(12), 1134-1140.

Cox, C., Watt, A. P., McKenna, J. P., \& Coyle, P. V. (2016). Mycoplasma hominis and Gardnerella vaginalis display a significant synergistic relationship in bacterial vaginosis. European Journal of Clinical Microbiology and Infectious Diseases, 35, 481-487.

Giraldo, P. C., Polpeta, N. C., \& Juliato, C. R. (2012). Evaluation of sexual function in brazilian women with recurrent vulvovaginal candidiasis and localized provoked. Jurnal of Sexual Medicine, 9(3), 805-811.

Goncharova, S. Y., Golodoc, L. P., \& Khlopov, A. V. (2015). Study of microflora the urogenital tract of women Dnepropetrovsky region using the method polymerase chain reaction. Biological Bulletin Melitopol State Pedagogical University named after Bogdan Khmelnitsky, 5(2), 75-84.

Goodman, A. (2015). HPV testing as a screen for cervical cancer. British Medical Journal, 350.

Haggerty, C. L., Totten, P. A., Tang, G., Astete, S. G., Ferris, M. J., Norori, J., Bass, D. C., Martin, D. H., Taylor, B. D., \& Ness, R. B. (2016). Identification of novel microbes associated with pelvic inflammatory disease and infertility. Sexually Transmitted Infections, 92(6), 441-446.

Hansen, D. S., Schumacher, H., \& Hansen, F. (2012). Extended-spectrum $\beta$-lactamase (ESBL) in danish clinical isolates of Escherichia coli and Klebsiella pneumoniae: Prevalence, $\beta$-lactamase distribution, phylogroups, and coresistance. Scandinavian Jurnal of Infectious Diseases, 44(3), 174-181.

Holloway, D. (2011). Vaginal thrush: Treating and advising the patient. British Journal of Nursing, 20(22), 1410.

Jacome-Galarza, I., Ito-Nakashimada, M. A., Figueroa-Aguilar, G., García-Latorre, E., Salazar, M. A., López-Orduña, E., Camacho, A. D., Valdez-Alarcón, J. J., Hernández, J. M., \& León-Avila, G. (2017). Prevalence of human papillomavirus in women from the State of Michoacan, Mexico, showed high frequency of unusual virus genotypes. Joumal Revista de Investigacion Clinica, 69(5), 262-269.

Klebanoff, M. A., Schwebke, J. R., Zhang, J., Nansel, T. R., Yu, K. F., \& Andrews, W. W. (2004). Vulvovaginal symptoms in women with bacterial vaginosis. Journal Ginecology and Obstetrics, 104(2), 267-272.
Leli, C., Mencacci, A., Latino, M. A., Clerici, P., Rassu, M., Perito, S., Castronari, R., Pistoni, E., Luciano, E., De Maria, D., Morazzoni, C., Pascarella, M., Bozza, S., \& Sensini, A. (2017). Prevalence of cervical colonization by Ureaplasma parvum, Ureaplasma urealyticum, Mycoplasma hominis and Mycoplasma genitalium in childbearing age women by a commercially available multiplex real-time PCR: An Italian observational multicentre study. Journal of Microbiology Immunology and Infection, 17, in press.

Linhares, J. J., Cavalcante, P. G., \& Vasconcelos, J. L. (2011). Prevalence of the colonization by Streptococcus agalactiae in pregnant women from a maternity in Ceará, Brazil, correlating with perinatal outcomes. Journal Ginecology and Obstetrics, 33(12), 395-400.

Louvanto, K., Rintala, M. A., Syrjänen, K. J., Grénman, S. E., \& Syrjänen, S. M. (2010). Genotype-specific persistence of genital human papillomavirus (HPV) infections in women followed for 6 years in the Finnish Family HPV Study. Jurnal of Infection Diseases, 202(3), 436-444.

Mollers, M., Boot Hein, J., Vriend Henrike, J., King Audrey, J., van den Broek Ingrid, V. F., van Bergen Jan, E. A., Brink Antoinette, A. T., Wolffs Petra, F. G., Hoebe Christian, J. P., Meijer Chris, J. L., van der Sande Marianne, A. B., \& de Melker Hester, E. (2013). Prevalence, incidence and persistence of genital HPV infections in a large cohort of sexually active young women in the Netherlands. Vaccine, 31(2), 394-401.

Nikulina, Y. Y., Sokolova, I. E., \& Vinnikov, A. I. (2012). Immunological changes in pregnant women with impaired dysbiotic. Bulletin of Dnipropetrovsk University. Biology, Medicine, 3(1), 85-90.

Potapov, V. A. (2014). Probiotics in gynecology. A fad or perceived need (analytical review, part 2). Wturbota Proinku, 57, 70-74.

Price, M. J., Ades, A. E., De Angelis, D., Welton, N. J., Macleod, J., Soldan, K., Simms, I., Turner, K., \& Horner, P. J. (2013). Risk of pelvicinflammatory disease following Chlamydia trachomatis infection: Analysis of prospective studies with a multistate model. American Jurnal of Epidemiology, 178, 484-492.

Rositch, A. F., Koshiol, J., Hudgens, M. G., Razzaghi, H., Backes, D. M. Pimenta, J. M., Franco, E. L., Poole, C., \& Smith, J. S. (2013). Patterns of persistent genital human papillomavirus infection among women worldwide: A literature review and meta-analysis. International Journal of Cancer, 133, 1271-1285.

Tian, T., Mijiti, P., Bingxue, H., Fadong, Z., Ainiwaer, A., Guoyao, S., Zhanlin, Z., Mahan, Y., Xiaoqin, T., Zheng, G., \& Jianghong, D. (2017). Prevalence and risk factors of anal human papillomavirus infection among HIV-negative men who have sex with men in Urumqi city of Xinjiang Uyghur Autonomous Region, China. International Journal of Infectious Diseases, 12(11), e0187928.

Winer, R. L., Xi, L. F., Shen, Z., Stern, J. E., Newman, L., Feng, Q., Hughes, J. P., \& Koutsky, L. A. (2014). Viral load and short-term natural history of typespecific oncogenic human papillomavirus infections in a high-risk cohort of midadult women. International Journal of Cancer, 134, 1889-1898.

Woodford, N. F., Turton, J., \& David, M. (2011). Multiresistant gram-negative bacteria: The role of high-risk clones in the dissemination of antibiotic resistance. Federation of European Microbiological Societies Microbiology Reviews, 35(5), 736-755.

Yoon, B., Romero, H. R., Lim, J. H., Shim, S. S., Hong, J. S., Shim, J. Y., \& Jun, J. K. (2003). The clinical significance of detecting Ureaplasma urealyticum by the polymerase chain reaction in the amniotic fluid of patients with preterm labor. American Journal Ginecology and Obstetrics, 189, 919-924.

Yoshida, T. S., Maeda, T., Deguchi, T., \& Ishiko, H. (2003). Rapid detection of Mycoplasma genitalium, Mycoplasma hominis, Ureaplasma parvum, and Ureaplasma urealyticum organisms in genitourinary samples by PCR-microtiter plate hybridization assay. Jumal of Clinical Microbiology, 4, 1850-1855.

Kaites, K. B., Katz, B., \& Schelonka, R. L. (2005). Mycoplasmas and Ureaplasmas as neonatal pathogens. Jurnal of Clinical Microbiology, 18(4), 757-789. 